\title{
THE CHEMICAL COMPOSITION, NUTRITION AND FRACTIONAL COMPOSITION OF WINTER RYE GRAIN PROTEINS AFTER VARIOUS METHODS OF EXPOSURE
}

\author{
Ziliya F. Fattakhova ${ }^{1 凶}$, Shamil K. Shakirov ${ }^{1}$, Evgeny O. Krupin¹, Irek T. Bikchantaev ${ }^{1}$, Liliya N. \\ Shayakhmetova ${ }^{1}$, Adela A. Askarova ${ }^{1}$ \\ ${ }^{1}$ Department of Agrobiological Research, Tatar Scientific Research Institute of Agriculture, FRC \\ Kazan Scientific Center, Russian Academy of Sciences 48, Orenburgsky tract str., \\ Kazan, 420059, Russia \\ Æattahova.zf@mail.ru
}

https://doi.org/10.34302/crpifst/2020.12.1.7

\begin{tabular}{ll}
\hline $\begin{array}{l}\text { Article history: } \\
\text { Received: }\end{array}$ & ABSTRACT \\
23 January 2019 & The choice of feed for cattle should be made by assessing the nutritional \\
value of the feed, as well as the animal's nutritional needs. Winter rye is a \\
major crop in northern latitudes and can be used as feed for livestock. Rye \\
18 January 2020 \\
grain contains a sufficient amount of protein, but its quality may not be \\
Keywords: & optimal for cattle to fully digest it. Nevertheless, there are a number of \\
Winter rye; & methods for processing the grain that can improve its nutritional properties, \\
Physicochemical processing & including by changing the fractional composition and solubility of its \\
methods; & proteins. This study analyzed the influence of thermal (toasting, autoclaving, \\
Sugar; & steaming, extrusion) and chemical (fermentation) methods for processing \\
Grain protein fractions; & winter rye grain. Toasting and extrusion led to the greatest changes in its \\
Protein degradability. & composition. After toasting the grain, the sugar content increased 5.81 times, \\
& while the amount of soluble fractions and protein degradability decreased by \\
& $17.92 \%$ and $11.65 \%$, respectively, in comparison to untreated grain. \\
& Extrusion processing of winter rye led to an increase in sugar, crude protein, \\
and metabolic energy by $49.82 \%, 32.24 \%$, and $22.53 \%$, respectively. The \\
insoluble fraction and protein non-degradability also increased by 1.22 and \\
1.13 times, respectively. The enzymatic treatment of rye grains led to an \\
increase in the insoluble fraction of proteins, as well as a significant increase \\
in the sugar content (by 5.75 times) compared to the control of untreated raw \\
materials. The results of this study can be used to develop optimal methods \\
for processing winter rye grain for cattle feed, taking into account the impact \\
on the nutritional properties of the grain, the subsequent effect on animal \\
productivity and the economic feasibility of the method.
\end{tabular}

\section{Introduction.}

Feeding livestock should be organized appropriately to include an accurate assessment of the nutritional value of feed and consider an animal's nutritional needs. Protein is a necessary element of good nutrition in cattle, and for dairy breeds in particular.
The main source of protein for ruminants is the biomass of rumen microorganisms, which is formed during the fermentation of feed (Schwab et al, 1995). During fermentation, proteins break down to form ammonia, which is then used either for the formation of urea in the liver, or for the synthesis of amino acids by rumen microorganisms. Part of the microbial biomass 
is removed from the rumen to the lower sections of the digestive tract, broken down in the abomasum and absorbed in the small intestine.

A number of publications indicate that the synthesis of essential amino acids by rumen microorganisms is not sufficient for animals with high productivity (Broderick, 2018). Therefore, when feeding animals, one should take into account not only the amount of protein, but also its breakdown in different parts of an animal's digestive tract. Using feeds with a higher fraction of protein that cannot be broken down in the rumen is an important strategy for increasing the productivity of cattle. This approach is more efficient and economical, has greater uniformity, and also takes into account the balance of essential amino acids in feed, their digestibility and taste (Schwab et al, 1995). There are a number of ways to increase the amount of protein that is not broken down in the rumen. These include thermal treatment (including the application of pressure), chemical treatment, fermentation, humidification, or a combination of these methods. Selecting the right method depends on the type of processed feed, its nutritional properties and the digestibility of the resulting product in the animal's intestines.

Rye, especially winter rye, is an important cereal crop in northern latitudes (in Canada, the northern regions of the USA, the European Union, and Russia), where it is highly adaptable and productive in various soil and climate conditions (Arendt \& Zannini, 2013). Rye grain has robust nutritional properties, including proteins, which can make up $7.0-14.6 \%$ of the grain's nutrition, depending on where it was cultivated and the variety (Hansen et al, 2004). The majority of these proteins $(70-80 \%)$ are prolamins and secalins, which are localized in the endosperm and perform a reserve function. The rest are globulins and albumin. This portion mainly consists of enzymes and structural proteins rich in essential amino acids such as lysine, histinin, arginine, and aspartic acid (Békés \& Wrigley, 2016; Schalk et al, 2017). However, an excess of readily available proteins, such as globulins and albumin, can adversely affect protein metabolism in cattle, leading to excessive ammonia production during fermentation and to an increase in nitrogen excretion in urine and feces, thereby reducing the efficiency of nitrogen use in the body (Schwab \& Broderick, 2017). In addition, winter rye grain contains a number of anti-nutritional substances, which include phytic acid, pentosans, pectins, $\beta$-glucans, tannins, trypsin and chymotrypsin inhibitors, and $\beta$ alkylresorcinol. They can reduce the efficiency of digestion, as well as the availability of nutrients, thereby affecting the growth of livestock (Lásztity, 1996).

Thus, given the prevalence of winter rye and its potential nutritional value, there is a need to search for technological methods to increase the nutritional value of winter rye for use as cattle feed. In this study, we evaluated the effects of various methods on the chemical and nutritional composition, as well as changes in protein fractions, in winter rye grain when preparing it as feed.

\section{Materials and methods}

This study used "Gift" grade winter rye (Secale cereale). This grade was developed by the "Federal Research Center Kazan Scientific Center of the Russian Academy of Sciences."

\subsection{Grain Processing Methods}

Toasting. The winter rye grain was prewetted with water until swelling. Next, the grain was poured in a thin layer onto an iron sheet and heated with constant stirring for 10-12 minutes at a temperature of $150^{\circ} \mathrm{C}$ until it was lightly browned (Isaichev et al, 2009).

Autoclaving. Before sterilization, the grain was mixed with water in a ratio of 1:1. The grain was then poured into heat-resistant containers and placed in an autoclave. Autoclaving was carried out under the following conditions: the vapor pressure in the sterilization chamber was 1.5-2 atmospheres, the operating temperature was $134^{\circ} \mathrm{C}$, the sterilization time was 60 minutes, and the volume of the autoclaving container was 1 liter (Stamets, 2000). 


\subsection{Steaming.}

The grain was ground, immersed in water, heated to a temperature of $95-100^{\circ} \mathrm{C}$ and infused for 120 minutes (Isaichev et al, 2009).

2.3.Extruding. A PE-1 press extruder (Penza, Russia) was used to process the grain. The crushed grain was placed in a press extruder and subjected to short-term but intense mechanical and barothermal action at high pressure (2.5-3.0 $\mathrm{MPa}$ ) at a temperature of $110-135^{\circ} \mathrm{C}$, as well as shearing forces in the mechanics of the apparatus. The finished product had a finely porous structure due to a sharp pressure drop when exiting the extruder (Morozkov \& Sitnikov, 2013).

2.4.Fermentation. Crushed winter rye grain was poured into a container in a 3:1 ratio with water heated to a temperature of $80-90^{\circ} \mathrm{C}$. Next, the NIST-2 polyenzyme complex (Russia), containing 550 units of alpha-amylase, gluconase (40 units), pectinase (150 units), xylanase (200 units) and protease (2 units), was added to the mixture in the amount of $0.1 \%$ of the grain mass and mixed thoroughly. The duration of this treatment was 2-3 hours.

\subsection{Analytical research.}

The mass fraction of crude protein was determined by the Kjeldahl method according to GOST 32044.1-2012 (ISO 5983-1:2005) (GOST 32044.1-2012, 2014); crude fiber - using intermediate filtration according to GOST 31675-2012 (GOST 31675-2012, 2014), crude fat - for skim residue according to GOST 13496.15-97 (GOST 13496.15-97, 2011). A fractional analysis of proteins in winter rye grains was done by determining the amount of protein in fractions taken after sequential extractions with water, weak solutions of neutral salts, alcohol and alkaline solutions. Each fraction was transferred to Kjeldahl flasks, burned with sulfuric acid, and the amount of nitrogen was determined according to Kjeldahl (GOST 13496.4-93 Feed, compound feed) (GOST 13496.4-93, 2011).

Protein digestibility was determined using a regression equation based on a direct relationship between protein digestibility and solubility in a buffer solution (Verite et al, 1979).

$$
\mathrm{P}=0.65 \times \mathrm{a}+35(\text { Eq. } 1)
$$

where:

$\mathrm{P}$ - degradability of crude protein;

a - solubility ( $\%$ of crude protein).

\section{Results and discussions}

3.1.The influence of physico-chemical exposure on the chemical composition and nutrition of winter rye

We compared the effects of various processing methods on the chemical composition (content of crude protein, fiber, fat and nitrogen-free extract [NFE]) and nutrition (energy exchange and sugar content) of winter rye grains (Table 1 ).

Table 1. The chemical composition and nutritional value of winter rye after various forms of physical and chemical exposure (in air-dry conditions

\begin{tabular}{|l|c|c|c|c|c|c|}
\hline \multirow{2}{*}{ Type of grain processing } & \multicolumn{3}{|c|}{ Chemical Composition, \% } & \multicolumn{2}{c|}{ Nutrition in 1 Kg } \\
\cline { 2 - 6 } & $\begin{array}{c}\text { Crude } \\
\text { protein }\end{array}$ & $\begin{array}{c}\text { Crude } \\
\text { fiber }\end{array}$ & $\begin{array}{c}\text { Crude } \\
\text { fat }\end{array}$ & NFE & $\begin{array}{c}\text { Metabolic } \\
\text { energy, } \\
\text { MJ }\end{array}$ & $\begin{array}{c}\text { Sugar } \\
\text { content, g }\end{array}$ \\
\hline Unprocessed grain & 8.87 & 2.35 & 1.79 & 78.09 & 13.98 & 56.00 \\
\hline Toasting & 9.01 & 2.37 & 1.51 & 77.06 & 13.79 & 325.5 \\
\hline Autoclaving & 9.57 & 3.05 & 1.87 & 76.51 & 13.92 & 64.00 \\
\hline Steaming & 9.28 & 3.02 & 1.50 & 77.49 & 13.96 & 246.00 \\
\hline Extruding & 10.73 & 4.08 & 1.07 & 77.52 & 14.13 & 83.90 \\
\hline Fermentation (NIST-2) & 8.96 & 2.27 & 1.23 & 75.43 & 13.46 & 322.00 \\
\hline
\end{tabular}


Heat treatment significantly improves the feed quality of grains, as it forms a large number of aromatic substances, increases enzymatic activity significantly, neutralizes toxins and kills toxin producers (Boyd et al, 2017). Toasting (conductive) gives the grain a pleasant taste and increases the digestibility of its starch. We analyzed the chemical composition of winter rye grains after toasting and found that this type of exposure contributed to a maximum increase in sugar content in winter rye up to $325.5 \mathrm{~g} / \mathrm{kg}$, which was 5.81 times higher than the control value (Table 1).

Autoclaving grains increases the availability of protein for digestion and the digestibility of dry matter. In addition, this method sterilizes the feed without reducing its nutritional properties 9McAllister et al, 1991). We found that autoclaving winter rye grains led to a significant increase in the proportion of crude fiber (by 34\%), the sugar content (by $14 \%$ ), and crude protein (by 7\%) compared to the control.

Steaming winter rye grains causes a significant increase in the concentration of sugars and fiber by 4.39 and 1.35 times, respectively, compared with the control. Elevated fiber levels are apparently caused by structural changes in carbohydrates.

Extrusion processing is one of the most effective methods of processing grain. Extrusion does two things: the source material is mechanically deformed and a loose structure is formed in the finished product due to the large pressure difference between the extruder and the atmosphere. These mechanisms rearrange the structure of the grain, which deactivates digestive tract enzyme inhibitors, neutralizes toxic substances, sterilizes, improves palatability, and dextrinizes the starch and part of the fiber into glucose (Rathod \& Annapure, 2016). Using extrusion on winter rye increases the content of not only sugar by $49.82 \%$ and crude protein by $32.24 \%$, but also metabolic energy by $22.53 \%$, compared with the control.
Fermenting feeds is another approach for increasing the availability of feed nutrients in which proteins, fats, and complex carbohydrates are broken down using enzymes. Fermentation can utilize microorganisms such as lactobacilli and yeast (Missotten et al, 2015; Skrede, 2007), or a mixture of hydrolase class enzymes (Rusakov \& Kosolapov, 2012). We studied the effect of using the NIST-2 polyenzyme complex on the chemical composition and nutritional value of winter rye grain. The NIST-2 enzyme complex contains enzymes that hydrolyze complex carbohydrates (alpha-amylase, gluconase, pectinase, xylanase). When treating winter rye grains with the NIST- 2 complex, a significant increase in the amount of sugars (5.75 times) was found in comparison with the control, untreated raw material.

All the methods for processing winter rye grain that we tested led to a decrease in the content of crude fat and the most significant decrease was observed in the extrusion of winter rye grains.

\subsection{The fractional composition of the protein after various types of physico-chemical exposure}

Along with increasing the overall nutritional value of feed for ruminants, it is very important to normalize the total level of protein, taking into account soluble fractions. The methods we studied for processing winter rye grain do not significantly affect the crude protein content in the processed grain, however, they can potentially affect its qualitative composition.

Among the proteins of cereal grains, including rye grains, water-soluble proteins, albumin, have the highest biological value. They contain all the essential amino acids in nearly optimal proportions, with only a slight deficiency in methionine content (Békés \& Wrigley, 2016). Rye grain has a high content of readily soluble protein fractions (Lásztity, 1996). When comparing the impact of different methods for processing rye grain on the albumin fraction, we found a that it decreased by $9.40 \%$ - $10.16 \%$ after using barothermal methods (frying, autoclaving and extrusion) compared to 
the control (Figure 1). Fermentation and steaming did not have a significant effect on the albumin fraction.

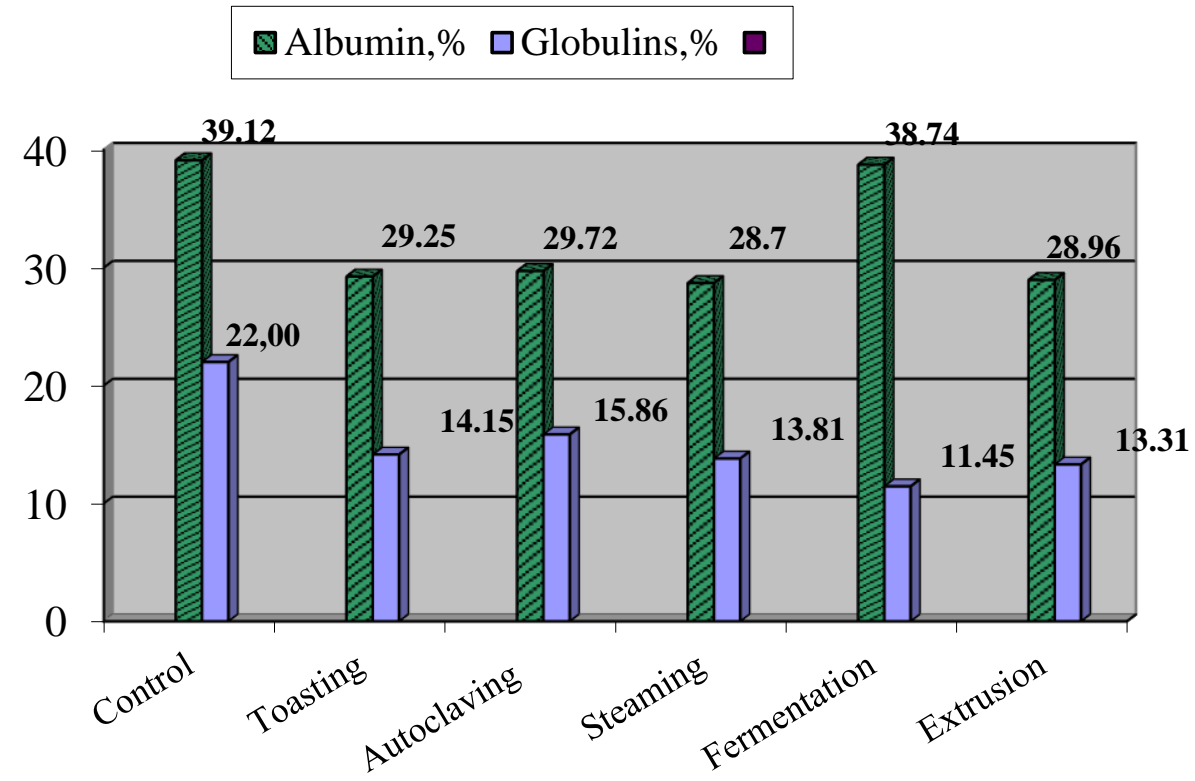

Figure 1. Changes in albumin and globulin protein fractions

The globulin protein fraction (salt-soluble grain proteins) is also characterized by a rather well-balanced amino acid composition, but has a reduced number of some essential amino acids (methionine, tryptophan, leucine) compared to albumin (Zilić et al, 2011). All the methods for processing rye grain studied had a similar effect with respect to decreasing the proportion of globulins. The maximum decrease in globulins was observed after high-temperature fermentation using NIST-2, which was $9.18 \%$ lower than the control. Autoclaving and toasting had a minimal impact $(6.15-7.85 \%$ compared with the control, respectively).

Rye prolamins (secalins) are reserve proteins in grains and have an unbalanced amino acid composition. They have a high proportion of glutamine, proline and glycine, which can be
$70-80 \%$ of all amino acid residues, as well as a reduced content of such essential amino acids as lysine, tryptophan, and methionine (Békés \& Wrigley, 2016; Wieser, 2008). Toasting, steaming and fermentation caused a significant decrease in the proportion of prolamins in rye grain, while autoclaving and extrusion had a less pronounced effect on these proteins (Figure 2). 


\section{$\square$ Prolamins, $\%$ G Glutelins, $\%$}

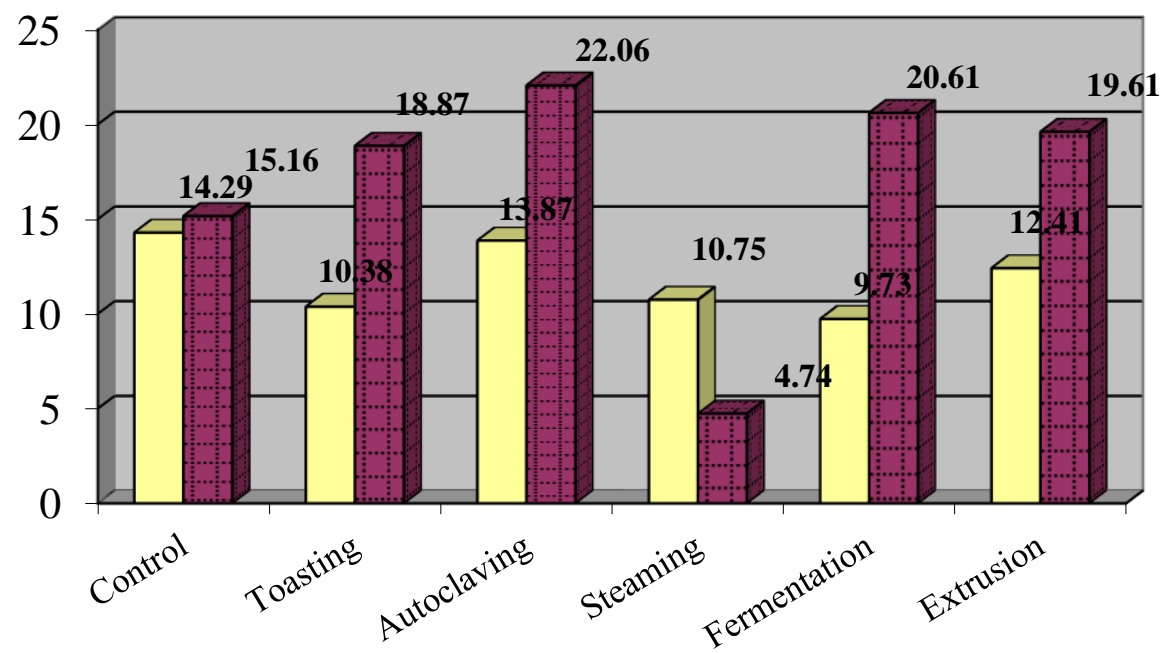

Figure 2. Changes in prolamine and glutelin protein fractions

A decrease in the amount of all soluble

Glutelins are also reserve proteins in rye grain and are characterized by a significant deficiency in lysine, tryptophan and methionine (Békés \& Wrigley, 2016). Fermentation and autoclaving significantly increased the proportion of glutelins in winter rye grain (by $5.45 \%$ and $6.90 \%$ more than the initial value, respectively). After toasting and extrusion, the increase was in the range of $3.1 \%-4.74 \%$, while steaming significantly reduced the content of glutelins (by more than three times). fractions is observed, compared to the control, after applying various methods for processing winter rye grain (Figure 3 ). It should be noted that the greatest decrease was found after extrusion and toasting (by 16.28\% - 17.92\%). After steaming, autoclaving, and fermentation, the decrease is in the range of $7.41 \%-10.04 \%$ compared to untreated grain.

Total of all soluble fractions $\square$ Protein degradability, \%

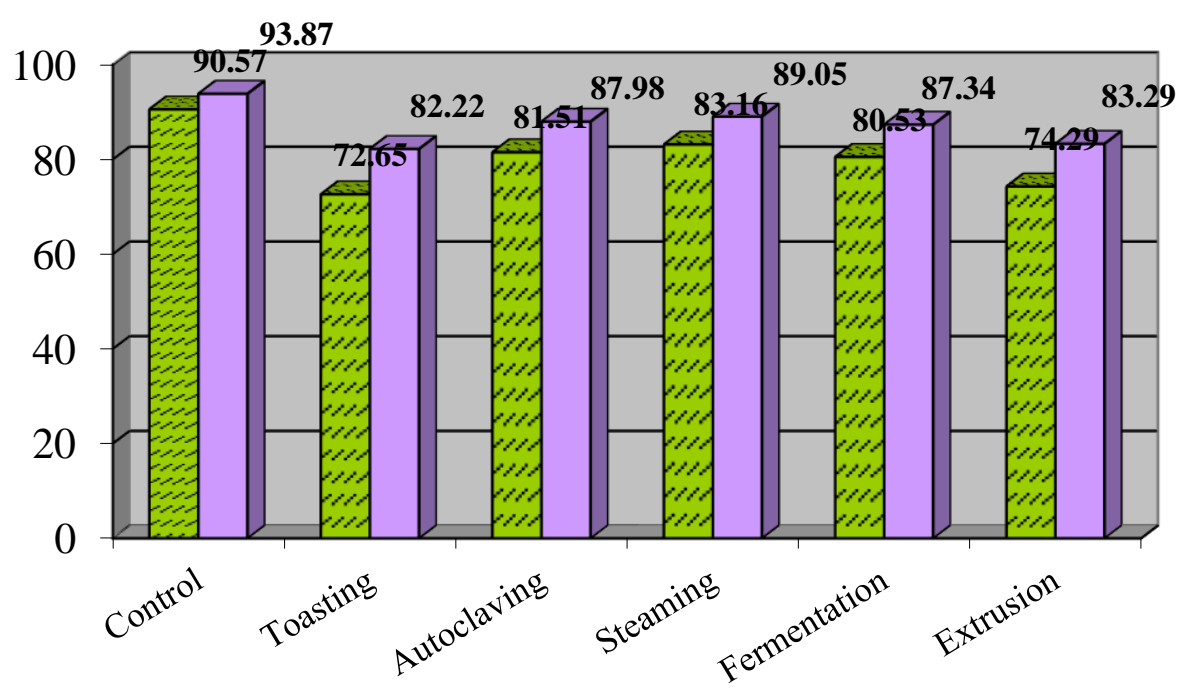

Figure 3. Changes in protein solubility and degradability 
A similar result was observed with respect to the proportion of degradable protein. The greatest decrease in this indicator was observed after toasting and extruding winter rye grain (by $11.65 \%$ and $10.58 \%$, respectively, compared with untreated grain). Other methods of grain processing had less of an impact on this indicator.

\subsection{Discussions}

This study is one of the first to compare various methods of physico-chemical exposure on winter rye grain for use as cattle feed. Winter rye is one of the most promising fodder plants in northern regions, as it is a frost-resistant crop that can grow in various types of soil. Both forage and grain feed made from rye have a high protein content, which can be a significant advantage of using rye as a feed crop. This factor should be taken into account when planning the diet of large and small cattle due to the unique features of their digestion. Using technologically simple and inexpensive methods for processing crude rye may be appropriate in this case.

Processing rye grain is done in global agricultural practice to improve its nutritional properties, its taste and to get rid of antinutritional substances. It has been shown that toasting increases the digestibility of feed consisting of $60 \%$ and $80 \%$ rye grain, mainly due to an increase in the digestibility of complex carbohydrates (Sharma et al, 1981). This is consistent with the increased sugar content observed after toasting.

In addition, preparing rye by flattening the grains and applying the MEC-SH1(Sibbiopharm LLC PA, Novosybirsk, Russian Federatrion) enzymatic complex containing hydrolytic enzymes increased the digestibility of the feed in vitro, and most importantly, increased productivity in cattle on this feed (Rusakov \& Kosolapov, 2012). Extruding rye grains also increases the sugar content of the feed and contributes to an increase in milk yield compared with animals from the control groups (Morozkov \& Sitnikov, 2013). In our research, toasting, extrusion, and high-temperature fermentation were found to contribute to an increase in sugar content. However, only future livestock research can confirm the effectiveness of the grain processing methods from this study in real agricultural practice.

An important observation is that all the methods we studied for processing winter rye reduced the fat content of the raw grain, with extrusion having the most pronounced effect ($39.1 \%$ ). This factor should be taken into account when using processed grain in cattle feed. Nevertheless, it should be noted that the methods for processing rye grain that we studied did not significantly reduce the value of total energy exchanged, which is promising for future use.

The development of feed for cattle should take into account the peculiarities of protein metabolism, including the proportion of proteins that are broken down and not broken down in the rumen. An increase in the fraction of proteins that are not digestible in the rumen in feed contributes to an increase in milk production in cows (summarized in (Boyd et al, 2017)). This is achieved via appropriate processing of the feed. We found that the methods we tested did not significantly affect the crude protein content in rye grain. However, they did affect the content of readily soluble protein fractions (albumin) (Figure 1), reduce the proportion of soluble protein fractions, and, to a lesser extent, protein breakdown (Figure 3), thereby increasing the amount of protein that is not broken down in the rumen.

Heat treatment of grain is the most common treatment method (Morozkov \& Sitnikov, 2013) and, according to the results of our study, seems to be most effective for increasing the fraction of protein that is not broken down in the rumen. Extrusion has similar properties. Steaming grain also reduced the amount of soluble protein fractions, but it also affected the glutelin fraction, reducing it by more than three times. Interestingly, the most effective decrease in the globulin fraction was observed after processing grain with the protease-containing preparation NIST-2, but this preparation had practically no effect on the albumin fraction. It is possible that 
using a higher concentration of proteases or selecting other enzymes could increase the efficiency of the enzymatic treatment of grain.

In addition to increasing the productivity of livestock, using various methods of grain processing to prepare feed for large and small cattle has other advantages. Studies on goats have shown that supplements containing protein that is not broken down in the rumen increase resistance in livestock to infection by gastrointestinal nematodes (Cériac et al, 2019). Using these supplements when feeding cattle, including dairy cows, can have the same effect.

In addition, much attention is currently being paid to the environmental impact of keeping livestock. Recently, Haro et al. showed that feeding sheep using feed with a high content of protein that is not digestible in the rumen reduces methane production, which is associated with global climate change processes (Haro et al, 2018). A number of other studies also confirm that processing feed reduces methane production in the rumen (Knapp et al, 2014). Thus, using locally sourced raw winter rye grains and processing them for livestock feed can contribute to reducing the environmental impact of animal husbandry.

\section{Conclusions}

Winter rye grain is appropriate feed for cattle, but physico-chemical treatment is recommended to increase its nutritional value. The methods for processing winter rye grain in this study influenced the qualitative and quantitative composition of nutrients in the grain and led to an increase in its sugar content, as well as an increase in its undigestible protein fraction, which is an essential component for feeding ruminants. This study can be used to further develop nutritious feed for cattle, thereby maximizing the productivity of livestock.

\section{References}

Arendt, E. \& Zannini, E. (2013). Cereal grains for the food and beverage industries. Woodhead Pub. Oxford, Philadelphia.
Békés, F. \& Wrigley, C.W. (2016). The Protein Chemistry of Cereal Grains. Elsevier. Oxford, United Kingdom.

Boyd, L., Storsley, J. \& Ames, N. (2017). Effect of Heat Treatments on Starch Pasting, Particle Size, and Color of Whole-Grain Barley. Cereal Chemistry Journal, № 2 (94), 325-332.

Broderick, G.A. (2018). Review: Optimizing ruminant conversion of feed protein to human food protein. Animal, № 8 (12), 1722-1734.

Cériac, S. et al. (2019). Supplementation with rumen-protected proteins induces resistance to Haemonchus contortus in goats. Scientific Reports, № 1 (9), 1237.

GOST 13496.15-97. (2011). Forages, compound feeds, raw material for compound feeds. Methods for determining the raw fat content. Moscow. [in Russian]

GOST 13496.4-93. (2011). Fodder, mixed fodder and animal feed raw stuff. Methods of nitrogen and crude protein determination. Moscow. [in Russian]

GOST 31675-2012. (2014). Feeds. Methods for determination of crude fibre content with intermediate filtration. Moscow. [in Russian]

GOST 32044.1-2012. (2014). Forages, compound feeds, raw material for compound feeds. Mass fraction calculation and calculation of crude protein weight ratio. Part 1. The Kjeldahl method. Moscow. [in Russian]

Hansen, H.B. et al. (2004). Grain Characteristics, Chemical Composition, and Functional Properties of Rye (Secale cereale L.) As Influenced by Genotype and Harvest Year. Journal of Agricultural and Food Chemistry, № 8 (52), 2282-2291.

Haro, A.N. et al. (2018). Protecting protein against ruminal degradation could contribute to reduced methane production. Journal of Animal Physiology and Animal Nutrition, № 6 (102), 1482-1487.

Isaichev, V.A. et al. (2009). Laboratory manual on storage, processing and standartization of 
crop farming products. Ulyanovsk: Stolypin State Agricultural University. [in Russian]

Knapp, J.R. et al. (2014). Invited review: Enteric methane in dairy cattle production: quantifying the opportunities and impact of reducing emissions. Journal of dairy science, № 6 (97), 3231-61.

Lásztity, R. (1996). The chemistry of cereal proteins. CRC Press. New York.

McAllister, T.A. et al. (1991). Selection of a sterilization method for the study of cereal grain digestion. Journal of Animal Science, № 7 (69), 3039-3043.

Missotten, J.A. et al. (2015). Fermented liquid feed for pigs: an ancient technique for the future. Journal of Animal Science and Biotechnology, № 1 (6), 4.

Morozkov, N.A. \& Sitnikov, V.A. (2013). Extruded rye in the diet of diary cows. Dostizhenia nauki i techniki APK, № 5, 5052. [in Russian]

Rathod, R.P. \& Annapure, U.S. (2016). Effect of extrusion process on antinutritional factors and protein and starch digestibility of lentil splits. LWT - Food Science and Technology, (66), 114-123.

Rusakov, R.V. \& Kosolapov, V.M. (2012). Efficiency of different methods of winter rye treatment in feeding of highly productive cows. Dostizhenia nauki i techniki APK, № 6, 61-65. [in Russian]

Schalk, K. et al. (2017). Isolation and characterization of gluten protein types from wheat, rye, barley and oats for use as reference materials. PLOS ONE, № 2 (12): e0172819.

Schwab, C.G. \& Broderick, G.A. (2017). A 100Year Review: Protein and amino acid nutrition in dairy cows. Journal of dairy science, № 12 (100), 10094-10112.

Schwab, C.G. (1995). Protected proteins and amino acids for ruminants. Weinheim: Wiley-VCH Verlag GmbH.
Sharma, H.R. et al. (1981). Evaluation of Rye Grain in the Diets of Young Holstein Calves and Lactating Dairy Cows. Journal of Dairy Science, № 3 (64), 441-448.

Skrede, A. et al. (2007). Effects of lactic acid fermentation and gamma irradiation of barley on antinutrient contents and nutrient digestibility in mink (Mustela vison) with and without dietary enzyme supplement. Archives of Animal Nutrition, № 3 (61), 211-221.

Stamets, P. (2000). Growing gourmet and medicinal mushrooms (3rd ed.) Ten Speed Press. Berekely, CA.

Verite, R. et al. (1979). new system for the protein feeding of ruminants: The PDI system. Livestock Production Science, № 4 (6), 349-367.

Wieser, H. (2008). Detection of gluten. Academic Press. Amsterdam.

Zilić, S. et al. (2011). Characterization of proteins from grain of different bread and durum wheat genotypes. International journal of molecular sciences, № 9 (12), 5878-94. 